\title{
Farklı Oranlarda Keçiboynuzu Unu İçeren Pestillerin Bazı Fiziksel, Kimyasal ve Duyusal Özelliklerinin Belirlenmesi
}

\author{
Emine Nakilcioğlu-Taş*, Büşra Çakaloğlu, Semih Ötleş
}

Ege Üniversitesi, Mühendislik Fakültesi, Glda Mühendisliği Bölümü, 35100 Bornova/İzmir, Türkiye

M A K A L E B İ L G İ S İ

Araştırma Makalesi

Geliş 26 Temmuz 2017

Kabul 17 Temmuz 2018

Anahtar Kelimeler:

Dut pestili

Hurma pestili

Keçiboynuzu unu

Protein

Fonksiyonel gida

*Sorumlu Yazar:

E-mail: emine.nakilcioglu@ege.edu.tr
Ö Z

Pestil; Türkiye' de genellikle kış aylarında tüketilmek üzere, dut, üzüm, kayısı, erik gibi birçok meyveden elde edilebilen vitamin ve mineral içeriği yüksek bir gıdadır. Yapılan bu çalışmada pestilin üretiminde kullanılan buğday nişastasının farklı oranlarda keçiboynuzu unu ile ikame edilmesi sonucunda elde edilen geleneksel ürünün protein içeriği ve dolayısıyla fonksiyonelliğinin artırılması amaçlanmaktadır. Bunun için dut ve hurma pestilleri, \%25-\%50-\%75 oranlarında keçiboynuzu unu ile ikame edilerek üretilmiştir. Pestillerin kimyasal kompozisyonları (nem, kül, yağ, protein, toplam karbonhidrat), enerji değerleri, kalınlık değerleri, $\mathrm{pH}$, titrasyon asitliği, HMF içerikleri, renk özellikleri ( $\left.\mathrm{L}^{*}, \mathrm{a}^{*}, \mathrm{~b}^{*}\right)$, mineral içerikleri $(\mathrm{Ca}, \mathrm{Fe}, \mathrm{K}, \mathrm{Mg}, \mathrm{Na}, \mathrm{Zn}, \mathrm{P})$ ve duyusal analizleri gerçekleştirilerek ürünlerin besinsel özellikleri ortaya konulmuştur ve analiz sonuçları tek yönlü varyans analizinden yararlanılarak istatiksel açıdan değerlendirilmiștir. Çalışmanın sonucunda keçiboynuzu unu ile ikame edilen pestillerin makro besin ögelerinde belirgin bir artış meydana geldiği ve dolayısıyla ürünün besleyici değerinin arttığ 1 tespit edilmiştir. Ayrıca \%25 oranında keçiboynuzu unu ikameli dut ve hurma pestillerinin duyusal açıdan renk, görünüş ve tat-koku özellikleri değerlendirildiğinde en çok beğenilen pestil örneği olduğu belirlenmiş̧tir.

Turkish Journal of Agriculture - Food Science and Technology, 6(8): 945-952, 2018

The Determination of Some Physical, Chemical and Sensory Properties of Pestil Containing Carob Flour at Different Ratio

\section{A R T I C L E IN F O}

\section{Research Article}

Received 26 July 2017

Accepted 17 July 2018

Keywords:

Mulberry pestil

Date pestil

Carob flour

Protein

Functional food

*Corresponding Author:

E-mail: emine.nakilcioglu@ege.edu.tr

\section{A B S T R A C T}

Pestil; is a traditional food with high vitamin and mineral content, which can be obtained from many fruit species such as mulberry, grape, apricot and plum and generally consumed in winter months in Turkey In this study, it is aimed to increase the protein content and thus the functionality of the traditional product which will be obtained as a result of replacing wheat starch used in pestil production with carob flour at different ratios. For this, mulberry and date pestils are produced by substituting carob flour at $25 \%$ - 50\% - 75\% ratios. The chemical compositions of pestils (moisture, ash, oil, protein, total carbohydrates), energy values, the thickness value, $\mathrm{pH}$, titration acidity, HMF content, colour characteristics $\left(\mathrm{L}^{*}, \mathrm{a}^{*}, \mathrm{~b}^{*}\right)$, mineral content $(\mathrm{Ca}, \mathrm{Fe}, \mathrm{K}, \mathrm{Mg}, \mathrm{Na}, \mathrm{Zn}, \mathrm{P})$, sensory analyses were carried out and the nutritional characteristics of the products were determined and the results of the analyses were evaluated statistically using one way ANOVA. As a result of the study, it was determined that pestils substituted with carob flour showed a significant increase in macro nutrients and this leads to increase at nutritive value. It was also determined that, mulberry and palm pestils, with $25 \%$ of locust bean flour substitutes are the most popular pestil samples when their sensory color, appearance and taste-odor properties are evaluated. 


\section{Giriş}

Kısa hasat mevsimi, çabuk bozulmaları ve soğuk ortamda depolanmaya olan duyarlılıkları nedeniyle, üzüm ve benzeri bazı meyvelerin raf ömürlerinin artırılması ihtiyacı ortaya çıkmaktadır (Maskan ve ark., 2002). Diğer bir deyişle, bu meyvelerin işlenerek raf ömrü daha uzun formlara dönüştürülmesi gerekmektedir (Mahmutoğlu et al., 1996). Pestil, yüksek besleyici bileşenleri olan doğal meyveler için ekonomik ve kullanışlı bir koruma yöntemi olmasıyla beraber faydalı bir atıştırmalıktır. İstenilen yapışkan kompozisyon elde edilene kadar ilgili karışımdan nemin uzaklaştırılmasıyla elde edilen pestil, nem oranının düşük olması nedeniyle uzun süre depolanabilmektedir (Moyls, 1981; Sharma et al., 2016).

Pestil, Türkiye'de üretimi ve tüketimi yaygın olarak gerçekleştirilen geleneksel bir üründür. Enerji ve mineral içeriği bakımından, özellikle de kalsiyum, potasyum, sodyum ve demir miktarları dikkate alındığında, zengin bir kaynak olduğu söylenilebilir. Raf ömrünün uzun olması, kış mevsimi için besleyici bir ürün olmasını sağlamaktadır (Çağındı ve Ötleş, 2005). Üretimi en yaygın olan pestil çeşitleri üzüm pestili, kayısı pestili, erik pestili ve dut pestilidir. Bunların yanı sıra; çilek pestili, , mango pestili, armut pestili gibi farklı pestil çeşitleri de bulunmasına rağmen tüketimlerinin yaygın olmadığ dikkatleri çekmektedir. Pestil üretiminde, değişik meyve kombinasyonları kullanılarak farklı aromaların eldesi mümkün kılınmaktadır (Suna ve ark., 2014).

Islak meyve püresinin düz bir zemin üzerindeki beze (kaput bezi) serilerek nemi uzaklaşıncaya kadar kurutulmasıyla elde edilen ürün olarak bilinen pestil (Çağındı ve Ötleş, 2005), Türk Standartları Enstitüsü’ ne göre, üzüm (TS 12680), erik (TS 12678), kayısı (TS 12679), dut (TS 12677) meyvelerinden elde edilen pulp veya meyve sularının gerektiğinde yenilebilir nişasta (TS 2970), beyaz şeker (TS 861), çeşni ve katkı maddeleri ilavesi ile tekniğine uygun olarak yoğunlaştırılmasından sonra usulüne uygun şekilde hazırlanıp kurutulması ile elde edilen bir mamul olarak tanımlanmaktadır.

Keçiboynuzu, baklagiller familyasına ait bir bitkidir. Yeryüzünün en eski bitkilerinden biri olduğu düşünülmekte ve Akdeniz iklimine sahip bölgelerde hiçbir suni katkıya ihtiyaç duymaksızın bol miktarda yetişebilmektedir (Tunalıoglu ve Özkaya, 2003; Demirtaş, 2007). Keçiboynuzunun çekirdeği; endosperm, kabuk ve tragasol olmak üzere üç kısımdan oluşmaktadır. Kabuk kısmının renk maddeleri kozmetik sektöründe kullanılmaktadır. Endosperm protein bakımından çok zengindir. Çekirdeği ise \%80-85 galaktomannan ve tragasol içermektedir (Kirk and Othmer, 1967; Yurdagel ve Teke, 1985). Toplam kuru maddesi yaklaşık \%91-92 oranında olan keçiboynuzu meyvesinde \%62-67 oranında şeker, \%4-6 protein, \%0,2-0,4 ham yăg, \%2-3 kül, \%4,66,2 ham selüloz ve diğer maddeler bulunmaktadır (Karkacıer ve Artık, 1995). Keçiboynuzu meyvesi tüketiminin antioksidan, anti-ishal, antibakteriyel, antiülser ve anti-inflamatuar etkileri de dahil olmak üzere özellikle sindirim sistemi üzerine farmakolojik etkilerinin bulunduğu kanıtlanmıştır (Rtibi et al., 2015a; Rtibi et al., 2016a; Rtibi et al., 2016b; Kivçak ve ark., 2002; Rtibi et al., 2015b; Rtibi et al., 2016c; Rtibi et al., 2017). Besleyici değeri ve sağlık etkileri bu derece yüksek olan keçiboynuzundan kek, pasta, ekmek, makarna, çikolata, peynir, dondurma, meyve jölesi ve marmelat yapımında faydalanılmaktadır (Kirk ve Othmer, 1967; Yurdagel ve Teke, 1985).

Pestil; enerji değeri yüksek, vitamin ve mineral maddelerce zengin, geleneksel bir ürün olmasına rağmen protein içeriği düşük bir gıdadır. Bu çalışmada buğday nişastasının farklı oranlarda keçiboynuzu unu ile ikame edilmesi sonucunda elde edilecek olan pestillerin başta protein içerikleri olmak üzere besin içeriklerinin de geliştirilmesi ve geleneksel bir ürünün fonksiyonelliğinin artırılması hedeflenmektedir. Böylece daha besleyici, inovatif bir g1da eldesi mümkün olacaktır. Literatürde buna benzer bir araştırmaya rastlanılmamış olması, çalışmanın özgünlüğü açısından önem arz etmektedir.

\section{Materyal ve Yöntem}

\section{Materyal}

Pestil üretiminde kullanılan buğday nişastası, keçiboynuzu unu ve briks dereceleri sırasıyla 72,6 ve 67,4 olarak belirlenen dut ve hurma pekmezleri piyasadan temin edilmiştir. Bu çalışmada bahsi geçen ingredientler kullanılarak keçiboynuzu unu katkısız kontrol örnekleri ile $\% 25, \% 50$ ve $\% 75$ oranlarında keçiboynuzu unu ikameli dut ve hurma pestili örnekleri üretilmiştir.

\section{Yöntem}

Dut ve hurma pestillerinin üretimi: Bu çalışmada şıradan pestil eldesi gerçekleştirilmiştir (Şekil 1). Dut ve hurma pekmezlerinin briks dereceleri 20 değerine ayarlanmıştır; 1/4'ü ayrılarak buğday nişastası ve keçiboynuzu unu karışımı (\%4, w/w) ile karıştırılmıştır. Kalan $3 / 4$ 'lük kısım ise 40 briks derecesine kadar koyulaştırılmıştır. Koyulaşan kısmın üzerine 1/4'lük kısımdan oluşturulan karışım ilave edilmiştir ve 10-16 dakika son briks derecesi 40 olana kadar kaynatma işlemine tabi tutulmuştur. Böylece herle yani pestilin bezlere serilmeden önceki son hali elde edilmiştir. Herle; kaput bezlerine, yaklaşık 0,5-2 mm kalınlıkta serilmiştir. Güneşte kurutma işlemine tabi tutulan pestiller, arka yüzleri hafif nemlendirilerek bezden ayrılmıştır. Üretilen pestiller, alçak yoğunluklu polietilen filmli ambalajlarda ve $+4^{\circ} \mathrm{C}$ ' de analize kadar saklanmıştır (Çağındı ve Ötleş, 2005).

$\mathrm{Bu}$ çalışma kapsamında keçiboynuzu unu katkısı olmaksızın üretilen 1 adet kontrol örneğinin yanı sıra 3 farklı oranda (\%25, \%50 ve \%75) keçiboynuzu unu ile ikame edilmiş pestil örnekleri üretilmiştir (Çizelge 1). İkame oranlarına ön denemeler sonucunda karar verilmiştir.

Pestil örneklerinde gerçekleştirilen analizler: Üretilen pestillerde nem tayini gravimetrik yöntemle TSE 1129ISO 1026 metoduna (TSE, 1998) göre, kül tayini gravimetrik yöntemiyle AOAC 940.36 metoduna uygun olarak (AOAC, 1990), protein tayini Kjeldhal yöntemiyle AOAC 920.152 metodu temel alınarak (AOAC, 1990), yağ tayini sokselet ekstraksiyonu ile gravimetrik olarak IUPAC 1.122 metoduna göre (IUPAC, 1979), toplam karbonhidrat miktarları nem, kül, protein ve yă miktarları toplamının 100'den çıkarılması sonucunda, 
enerji değeri ise karbonhidrat ve protein içeriklerinin 4 ile, yăg içeriklerinin ise 9 ile çarpılıp toplanması sonucunda belirlenmiştir.

Çizelge 1 Keçiboynuzu unu ikame oranları Table 1 The substitution rates of carob flour

\begin{tabular}{l|l}
\multicolumn{1}{c}{ Pestiller } & \multicolumn{1}{c}{$\begin{array}{c}\text { Formülasyondaki keçiboynuzu unu } \\
\text { oranlar1 }\end{array}$} \\
\hline DK & $\% 100$ Nişasta \\
D25 & $\% 75$ Nişasta $+\% 25$ Keçiboynuzu unu \\
D50 & $\% 50$ Nişasta $+\% 50$ Keçiboynuzu unu \\
D75 & $\% 25$ Nişasta $+\% 75$ Keçiboynuzu unu \\
HK & $\% 100$ Nişasta \\
H25 & $\% 75$ Nişasta $+\% 25$ Keçiboynuzu unu \\
H50 & $\% 50$ Nişasta $+\% 50$ Keçiboynuzu unu \\
H75 & $\% 25$ Nişasta $+\% 75$ Keçiboynuzu unu \\
\hline
\end{tabular}

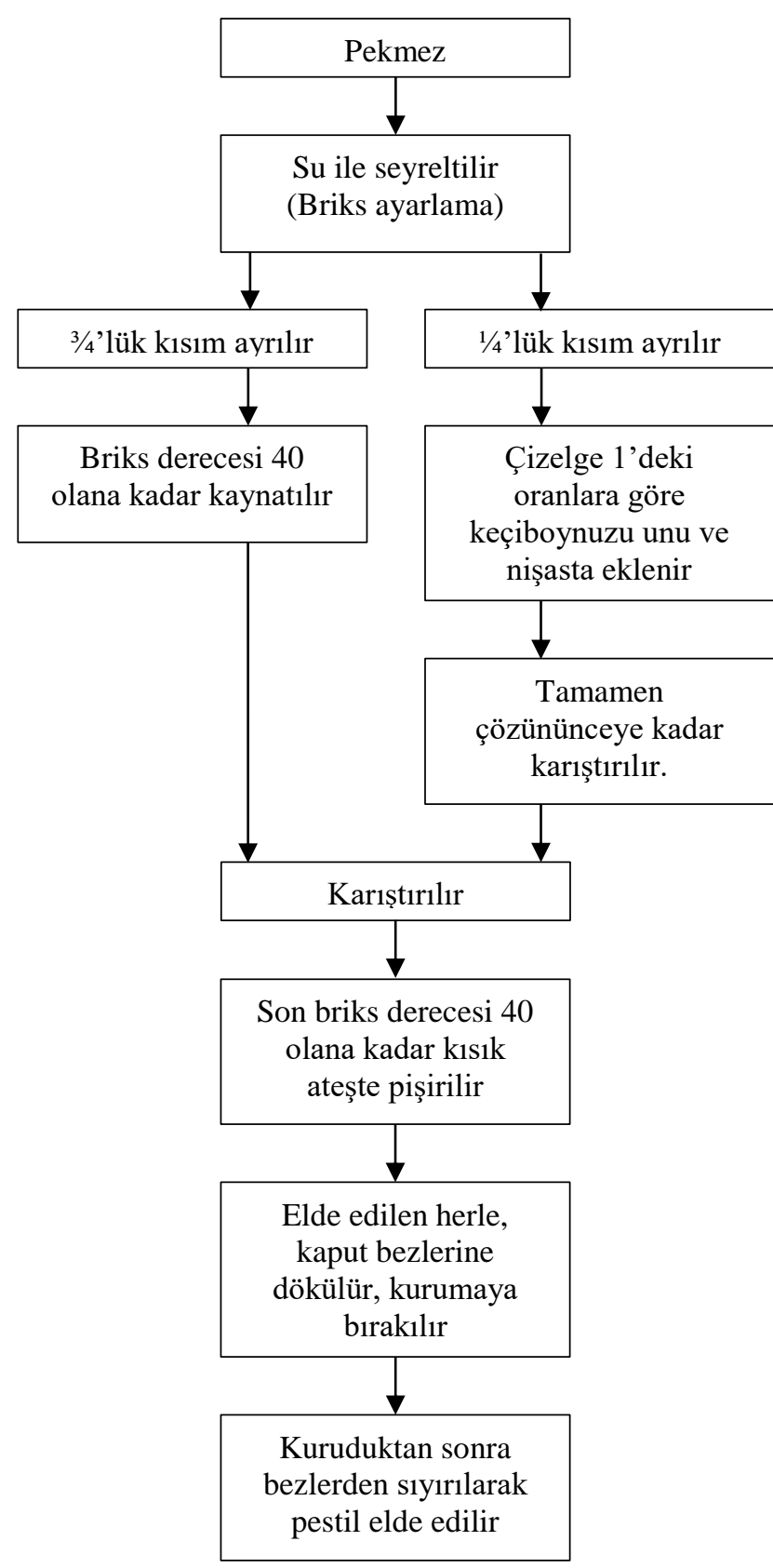

Şekil 1 Pestil üretim akım șeması (Şekilde Figure 1 The flow sheet of pestil production
Pestil örneklerinin $\mathrm{Ca}, \mathrm{Fe}, \mathrm{K}, \mathrm{Mg}, \mathrm{Na}$ ve Zn içerikleri Atomik Absorpsiyon Spektrofotometresi (Analytik Jena ContrAA 700, Almanya) yardımıyla, fosfor miktarları ise AOAC (1966) yöntemine göre spektrofotometrik olarak UV/VIS Spektrofotometre (Optizen Pop, Mecasys Co., Ltd., Kore) kullanımıyla ortaya konulmuştur. Örneklerin sitrik asit cinsinden titrasyon asitliği AOAC (1995) metoduna uygun olarak, $\mathrm{pH}$ değerleri Inolab $\mathrm{pH} 720$ (WTW GmbH, Almanya) marka pH metre yardımı ile, suda çözünür kuru madde (briks) tayini Abbe Refraktometresi kullanımıyla, 5-hidroksimetilfurfural (HMF) analizi yüksek performans sıvı kromotografisi (Agilent 1200 LC sistem, ABD) ile Rada-Mendoza (2002) tarafindan uygulanılan metoda göre, renk tayini Minolta (CR-400 Model Kolorimetre, Konica Minolta Sensing, Inc., Japonya) ölçüm cihazı kullanılarak CIElab modunda $\mathrm{L}^{*}, \mathrm{a}^{*}, \mathrm{~b}^{*}$ değerlerinin belirlenmesi ve değerlerden kroma*, Hue açısı* ve toplam renk değişiminin tespit edilmesiyle, kalınlık tayini ise kumpas kullanılarak gerçekleştirilmiştir. Örneklerin duyusal analizi puanlama testi kullanılarak yapılmıştır. Duyusal değerlendirme TSE 12677'de verilen skala kullanılarak 10 panelistin örnekleri renk, görünüş, tat ve koku özelliklerine göre 1-4 arası puanlamaları ile gerçekleştirilmiştir (TSE, 2000).

\section{Istatistiksel Analiz}

SPSS 20.0 paket programı kullanılarak analiz sonuçları tek yönlü varyans analizi ve Duncan testi yardımıyla istatistiksel açıdan değerlendirilmiştir. Kontrol, \%25, \%50 ve \%75 oranında keçiboynuzu unu ikameli örnekler arasında anlamlı bir farklılığın olup olmadığının belirlenmesi için, dut ve hurma pestili örnekleri kendi içlerinde değerlendirilmiştir $(\mathrm{P}<0,05)$

\section{Bulgular ve Tartışma}

Keçiboynuzu İkameli Dut Pestillerinin Bazı Fiziksel, Kimyasal ve Duyusal Özellikleri

Keçiboynuzu unu ikamesi ile elde edilen dut pestillerinin bazı kimyasal özellikleri Çizelge 2'de gösterilmiştir. Buna göre örneklerin nem miktarları $\% 10,96-\% 12,29$ aralığında, yağ içerikleri \%0,021-\%0,028 arasında, protein miktarları \%1,23-\%1,86 arasında, kül miktarlar1 \%1,73-\%1,84, toplam karbonhidrat miktarları $\% 84,63-\% 86,46$ aralığında ve enerji değerleri \%343,63 $\mathrm{kkal} / 100 \mathrm{~g}-351,75 \mathrm{kkal} / 100 \mathrm{~g}$ aralığında tespit edilmiştir. Dut pestili örneklerinin kül, toplam karbonhidrat ve enerji değerleri arasında istatistiksel açıdan anlamlı bir farklılık bulunmamasına rağmen $(\mathrm{P}>0,05)$, örneklerin incelenen diğer besin öğeleri miktarları arasındaki farklılık istatistiksel açıdan anlamlıdır $(\mathrm{P}<0,05)$. Keçiboynuzu unu ikamesinin, dut pestilinin özellikle yağ ve protein değerlerinde artışa sebep olduğu göze çarpmaktadır. Bu çalışmada elde edilen sonuçlar, Ekşi ve Artık (1984) ve Çağındı ve Ötleş (2005) tarafından gerçekleştirilen çalışmalarda kullanılan dut pestili örneklerinin besin içeriği değerleriyle paralellik göstermektedir.

Çizelge 3'te keçiboynuzu ikamesi ile elde edilen dut pestillerinin diğer kimyasal özellikleri yer almaktadır. Buna göre dut pestillerinin $\mathrm{pH}$ değerlerinin 6,19-6,88, sitrik asit cinsinden titrasyon asitliklerinin \%2,49- \%3,76, suda çözünür kuru madde değerlerinin (briks derecesinin) 21,51-34,01- ve HMF değerlerinin 11,62 mg/kg-26,55 
$\mathrm{mg} / \mathrm{kg}$ aralığında değiştiği gözlemlenmiştir. En yüksek $\mathrm{pH}$ değerinin D25'e ait olduğu, en yüksek briks derecesine sahip örneğin DK olduğu, en yüksek HMF değerine sahip örneğin D50 olduğu belirlenmiştir $(\mathrm{P}<0,05)$. DK ve D50 örneklerinin titrasyon asitlik değerinin ise en yüksek olduğu ortaya çıkmıştır $(\mathrm{P}<0,05)$. Bununla beraber keçiboynuzu unu ilavesinin $\mathrm{pH}$ değerlerinde, titrasyon asitliğinde, briks derecesinde ve HMF değerlerinde değişikliklere neden olduğu görülmektedir. Boz (2012) ve Yildız (2013)'1n çalışmalarında dut pestilinde belirledikleri $\mathrm{pH}$, titrasyon asitliği ve HMF miktarlarıyla bu çalışmadan elde edilen sonuçlar uyumludur.

Keçiboynuzu ikamesi ile elde edilen dut pestillerinin mineral madde miktarları Çizelge 4'te görülmektedir. Dut pestilinde yapilan mineral madde tayininde kalsiyum miktarlarına bakıldığında en yüksek değerin D50 ile D75 örneklerine ait olduğu ve bu iki örneğin kalsiyum miktarları arasında istatistiksel açıdan anlamlı bir farklılığın olmadığı, demir ve magnezyum miktarlarının keçiboynuzu ikamesi ile artış gösterirken çinko miktarında azalmaya yol açtığı göze çarpmıştır $(\mathrm{P}<0,05)$. En düşük sodyum miktarına sahip örnekler DK ve D25 iken, keçiboynuzu ikamesi ile pestillerin potasyum içeriğinde bir artış meydana geldiği fakat bu artışın ikame oranından bağımsız olduğu dikkatleri çekmiştir $(\mathrm{P}<0,05)$. Fosfor içerikleri incelendiğinde en yüksek fosfor miktarına sahip örneğin DK ile D50 ve en düşük fosfor miktarına sahip örneğin ise D75 olduğu ve aralarında istatistiksel açıdan anlamlı bir farklılığın bulunduğu göze çarpmakla beraber keçiboynuzu unu ilavesinin örneklerdeki fosfor içeriğini azaltma yönünde etki ettiği görülmüştür $(\mathrm{P}<0,05)$. Genel olarak bu çalışmadan elde edilen sonuçlara yakın veriler, Çağındı ve Ötleş (2005) ile Ekşi ve Artık (1984) tarafindan gerçekleştirilen çalışmalarda da elde edilmiştir. Buna rağmen pestilin mineral madde içeriğine ait literatür verileri ile bu çalışmadan elde edilen sonuçlar arasında gözlenen farklılıkların sebebinin pestil eldesinde kullanılan hammaddelerdeki farklılıktan ileri geldiği düşünülmektedir.

Çizelge 5'de keçiboynuzu ikamesi ile elde edilen dut pestillerine ait kalınlık ve renk değerleri belirtilmiştir. Çizelgeye göre pestil örneklerinin kalınlık değerlerinin $0,91 \mathrm{~mm}$ ile $1,02 \mathrm{~mm}$ aralığında değiştiği ancak istatistiksel açıdan örnekler arasında anlamlı bir farklılığın olmadığı göze çarpmaktadır $(\mathrm{P}<0,05)$. Kalınlığın homojen ve örnekler arasında benzer olması, istenilen ve beklenilen bir durumdur. Literatürde pestilde kalınlığın renk üzerinde önemli bir etkiye sahip olduğu ifade edilmektedir (Çağındı ve Ötleş, 2005). Dut pestili örneklerinin renk değerlerinden, aydınlık değerini veren L* değeri 36,46-38,42, kırmızılık-yeşillik indeksi olan a* değeri 1,84-7,75, sarılık-mavilik indeksi olan $b^{*}$ değeri $1,55-1,75$, renk tonunu gösteren Hue* değeri 10,56175,68 ve doygunluk indeksi olan kroma* değeri 2,427,97 arasında değişmektedir.

Çizelge 2 Keçiboynuzu unu ikamesi ile üretilen dut pestillerinin bazı kimyasal özellikleri Table 2 Some chemical properties of mulberry pestil produced with carob flour substitute

\begin{tabular}{c|ccccccc}
\hline PK & Nem $(\%)$ & TKM $(\%)$ & Yağ $(\%)$ & Protein $(\%)$ & Kül $(\%)$ & TK $(\%)$ & E $(k k a l / 100 \mathrm{~g})$ \\
\hline DK & $12,29 \pm 0,61^{\mathrm{a}}$ & $87,71 \pm 0,61^{\mathrm{b}}$ & $0,021 \pm 0,00^{\mathrm{b}}$ & $1,23 \pm 0,08^{\mathrm{c}}$ & $1,81 \pm 0,06^{\mathrm{a}}$ & $84,63 \pm 0,87^{\mathrm{a}}$ & $343,63 \pm 3,18^{\mathrm{a}}$ \\
D25 & $11,34 \pm 0,14^{\mathrm{a}, \mathrm{b}}$ & $88,66 \pm 0,14^{\mathrm{a}, \mathrm{b}}$ & $0,023 \pm 0,00^{\mathrm{a}, \mathrm{b}}$ & $1,28 \pm 0,01^{\mathrm{c}}$ & $1,84 \pm 0,18^{\mathrm{a}}$ & $85,50 \pm 0,35^{\mathrm{a}}$ & $347,36 \pm 1,36^{\mathrm{a}}$ \\
D50 & $10,96 \pm 0,11^{\mathrm{b}}$ & $89,04 \pm 0,11^{\mathrm{a}}$ & $0,024 \pm 0,00^{\mathrm{a}, \mathrm{b}}$ & $1,42 \pm 0,06^{\mathrm{b}}$ & $1,79 \pm 1,32^{\mathrm{a}}$ & $86,46 \pm 1,24^{\mathrm{a}}$ & $351,75 \pm 4,69^{\mathrm{a}}$ \\
D75 & $11,36 \pm 0,12^{\mathrm{ab}}$ & $88,64 \pm 0,12^{\mathrm{a}, \mathrm{b}}$ & $0,028 \pm 0,00^{\mathrm{a}}$ & $1,86 \pm 0,01^{\mathrm{a}}$ & $1,73 \pm 0,11^{\mathrm{a}}$ & $85,00 \pm 0,29^{\mathrm{a}}$ & $347,68 \pm 1,23^{\mathrm{a}}$ \\
\hline
\end{tabular}

PK: Pestil Kodları, TKM: Toplam Kuru Madde, TK: Toplam Karbonhidrat, E: Enerji, Analiz sonuçları "ortalama \pm standart sapma" şeklinde ifade edilmiştir. Aynı sütundaki farklı üstel ifadeye sahip ortalamalar arasında, istatistiksel açıdan anlamlı bir fark bulunmaktadır $(\mathrm{P}<0,05)$.

Çizelge 3 Keçiboynuzu unu ikamesi ile üretilen dut pestillerinin belirlenen diğer kimyasal özellikleri Table 3 The other determined chemical properties of mulberry pestil produced with carob flour substitute

\begin{tabular}{c|cccc}
\hline PK & $\mathrm{pH}$ & Titrasyon asitliği (sitrik asit cinsinden) & ${ }^{\circ}$ Briks & HMF $(\mathrm{mg} / \mathrm{kg})$ \\
\hline DK & $6,19 \pm 0,03^{\mathrm{c}}$ & $3,76 \pm 0,07^{\mathrm{a}}$ & $34,01 \pm 0,00^{\mathrm{a}}$ & $23,29 \pm 0,30^{\mathrm{b}}$ \\
D25 & $6,88 \pm 0,01^{\mathrm{a}}$ & $2,49 \pm 0,00^{\mathrm{c}}$ & $18,83 \pm 0,00^{\mathrm{d}}$ & $11,62 \pm 0,07^{\mathrm{d}}$ \\
D50 & $6,22 \pm 0,02^{\mathrm{b}, \mathrm{c}}$ & $3,65 \pm 0,47^{\mathrm{a}, \mathrm{b}}$ & $23,31 \pm 0,01^{\mathrm{b}}$ & $26,55 \pm 0,01^{\mathrm{a}}$ \\
D75 & $6,26 \pm 0,03^{\mathrm{b}}$ & $3,28 \pm 0,93^{\mathrm{b}}$ & $21,51 \pm 0,00^{\mathrm{c}}$ & $22,69 \pm 0,16^{\mathrm{c}}$ \\
\hline
\end{tabular}

PK: Pestil Kodları, Analiz sonuçları "ortalama \pm standart sapma” şeklinde ifade edilmiştir. Aynı sütundaki farklı üstel ifadeye sahip ortalamalar arasında, istatistiksel açıdan anlamlı bir fark bulunmaktadır $(\mathrm{P}<0,05)$.

Çizelge 4 Keçiboynuzu unu ikamesiyle üretilen dut pestillerinin mineral madde miktarları Table 4 Mineral contents of mulberry pestil produced with carob flour substitute

\begin{tabular}{l|ccccccc}
\hline PK & Ca $(\mathrm{mg} / \mathrm{kg})$ & $\mathrm{Fe}(\mathrm{mg} / \mathrm{kg})$ & $\mathrm{K}(\mathrm{mg} / \mathrm{kg})$ & $\mathrm{Mg}(\mathrm{mg} / \mathrm{kg})$ & $\mathrm{Na}(\mathrm{mg} / \mathrm{kg})$ & $\mathrm{Zn}(\mathrm{mg} / \mathrm{kg})$ & $\mathrm{P}(\mathrm{mg} / \mathrm{kg})$ \\
\hline DK & $123,2 \pm 0,28^{\mathrm{c}}$ & $39,73 \pm 1,05^{\mathrm{d}}$ & $208,85 \pm 0,42^{\mathrm{b}}$ & $37,59 \pm 0,07^{\mathrm{c}}$ & $163,45 \pm 0,07^{\mathrm{c}}$ & $33,53 \pm 0,09^{\mathrm{a}}$ & $563,70 \pm 8,76^{\mathrm{a}}$ \\
D25 & $199,95 \pm 13,29^{\mathrm{b}}$ & $63,745 \pm 0,60^{\mathrm{c}}$ & $220,7 \pm 0,56^{\mathrm{a}}$ & $37,66 \pm 0,01^{\mathrm{c}}$ & $164,25 \pm 0,49^{\mathrm{b}, \mathrm{c}}$ & $30,63 \pm 0,24^{\mathrm{b}}$ & $427,42 \pm 78,84^{\mathrm{b}}$ \\
D50 & $348,9 \pm 11,24^{\mathrm{a}}$ & $74,69 \pm 0,33^{\mathrm{b}}$ & $224,6 \pm 0,35^{\mathrm{a}}$ & $39,245 \pm 0,19^{\mathrm{b}}$ & $166,25 \pm 0,49^{\mathrm{a}}$ & $27,22 \pm 0,31^{\mathrm{c}}$ & $495,56 \pm 35,04^{\mathrm{a}, \mathrm{b}}$ \\
D75 & $375,6 \pm 10,74^{\mathrm{a}}$ & $78,835 \pm 1,55^{\mathrm{a}}$ & $228,65 \pm 5,58^{\mathrm{a}}$ & $39,85 \pm 0,05^{\mathrm{a}}$ & $165,05 \pm 0,77^{\mathrm{a}, \mathrm{b}}$ & $26,86 \pm 0,39^{\mathrm{c}}$ & $49,55 \pm 0,00^{\mathrm{c}}$ \\
\hline
\end{tabular}

PK: Pestil Kodları, Analiz sonuçları “ortalama \pm standart sapma” şeklinde ifade edilmiştir. Aynı sütundaki farklı üstel ifadeye sahip ortalamalar arasında, istatistiksel açıdan anlamlı bir fark bulunmaktadır $(\mathrm{P}<0,05)$. 
Çizelge 5 Keçiboynuzu unu ikamesiyle üretilen dut pestillerinin renk ve kalınlık değerleri

Table 5 Colour and thickness values of mulberry pestil produced with carob flour substitute

\begin{tabular}{c|ccccccc}
\hline PK & Kalınlk $(\mathrm{mm})$ & $\mathrm{L}^{*}$ & $\mathrm{a}^{*}$ & $\mathrm{~b}^{*}$ & Kroma* $^{*}$ & Hue* & $\begin{array}{c}\text { Toplam renk } \\
\text { değişimi }\end{array}$ \\
\hline DK & $0,91 \pm 0,09^{\mathrm{a}}$ & $36,46 \pm 0,40^{\mathrm{b}}$ & $7,72 \pm 0,61^{\mathrm{a}}$ & $1,46 \pm 0,52^{\mathrm{a}}$ & $7,87 \pm 0,69^{\mathrm{a}}$ & $1,56 \pm 2,29^{\mathrm{c}}$ & - \\
D25 & $1,02 \pm 0,18^{\mathrm{a}}$ & $37,26 \pm 0,92^{\mathrm{b}}$ & $7,7 \pm 0,78^{\mathrm{a}}$ & $1,75 \pm 0,89^{\mathrm{a}}$ & $7,97 \pm 0,93^{\mathrm{a}}$ & $12,34 \pm 5,29^{\mathrm{c}}$ & $1,34 \pm 1,04^{\mathrm{c}}$ \\
D50 & $0,94 \pm 0,15^{\mathrm{a}}$ & $38,42 \pm 0,25^{\mathrm{a}}$ & $4,1 \pm 0,71^{\mathrm{b}}$ & $-0,30 \pm 0,35^{\mathrm{b}}$ & $4,22 \pm 0,71^{\mathrm{b}}$ & $175,68 \pm 5,11^{\mathrm{a}}$ & $4,22 \pm 0,49^{\mathrm{b}}$ \\
D75 & $0,93 \pm 0,13^{\mathrm{a}}$ & $37,17 \pm 0,37^{\mathrm{b}}$ & $1,84 \pm 0,23^{\mathrm{c}}$ & $-1,55 \pm 0,11^{\mathrm{c}}$ & $2,42 \pm 0,11^{\mathrm{c}}$ & $139,19 \pm 5,57^{\mathrm{b}}$ & $6,39 \pm 0,22^{\mathrm{a}}$ \\
\hline
\end{tabular}

PK: Pestil Kodları, Analiz sonuçları "ortalama \pm standart sapma" şeklinde ifade edilmiştir. Aynı sütundaki farklı üstel ifadeye sahip ortalamalar arasında, istatistiksel açıdan anlamlı bir fark bulunmaktadır $(\mathrm{P}<0,05)$.

Çizelge 6 Keçiboynuzu unu ikamesiyle üretilen dut pestillerinin duyusal özellikleri Table 6 Sensory properties of mulberry pestil produced with carob flour substitute

\begin{tabular}{c|ccc}
\hline PK & Renk & Görünüş & Tat-Koku \\
\hline DK & $3.7 \pm 0.48^{\mathrm{a}}$ & $3.3 \pm 0.48^{\mathrm{a}}$ & $4.0 \pm 0.00^{\mathrm{a}}$ \\
D25 & $3.9 \pm 0.32^{\mathrm{a}}$ & $3.5 \pm 0.70^{\mathrm{a}}$ & $3.1 \pm 0.1^{\mathrm{b}}$ \\
D50 & $3.1 \pm 0.32^{\mathrm{b}}$ & $2.7 \pm 0.48^{\mathrm{b}}$ & $3.0 \pm 0.00^{\mathrm{b}}$ \\
D75 & $3.0 \pm 0.00^{\mathrm{b}}$ & $2.2 \pm 0.42^{\mathrm{c}}$ & $2.0 \pm 0.15^{\mathrm{c}}$ \\
\hline
\end{tabular}

PK: Pestil Kodları, Analiz sonuçları "ortalama \pm standart sapma" şeklinde ifade edilmiştir. Aynı sütundaki farklı üstel ifadeye sahip ortalamalar arasında, istatistiksel açıdan anlamlı bir fark bulunmaktadır $(\mathrm{P}<0,05)$.

Çizelge 7 Keçiboynuzu unu ikamesi ile üretilen hurma pestillerinin bazı kimyasal özellikleri

Table 7 Some chemical properties of date pestil produced with carob flour substitute

\begin{tabular}{c|ccccccc}
\hline PK & Nem $(\%)$ & TKM $(\%)$ & Yağ $(\%)$ & Protein $(\%)$ & Kül $(\%)$ & TK $(\%)$ & E (kkal/100 gr) \\
\hline HK & $15,48 \pm 0,16^{\mathrm{c}}$ & $84,52 \pm 0,15^{\mathrm{a}}$ & $0,0427 \pm 0,00^{\mathrm{b}}$ & $1,83 \pm 0,0^{\mathrm{b}}$ & $1,62 \pm 0,06^{\mathrm{a}}$ & $81,05 \pm 0,27^{\mathrm{a}}$ & $331,72 \pm 1,07^{\mathrm{a}}$ \\
H25 & $17,60 \pm 0,13^{\mathrm{a}}$ & $82,40 \pm 0,13^{\mathrm{c}}$ & $0,0441 \pm 0,00^{\mathrm{b}}$ & $2,04 \pm 0,07^{\mathrm{a}}$ & $1,77 \pm 0,24^{\mathrm{a}}$ & $78,53 \pm 0,37^{\mathrm{c}}$ & $322,65 \pm 1,74^{\mathrm{b}}$ \\
H50 & $16,20 \pm 0,16^{\mathrm{b}}$ & $83,80 \pm 0,12^{\mathrm{b}}$ & $0,0447 \pm 0,00^{\mathrm{b}}$ & $2,06 \pm 0,03^{\mathrm{a}}$ & $1,68 \pm 0,24^{\mathrm{a}}$ & $80,00 \pm 0,44^{\mathrm{b}}$ & $328,64 \pm 1,89^{\mathrm{a}}$ \\
H75 & $16,44 \pm 0,15^{\mathrm{b}}$ & $83,56 \pm 0,16^{\mathrm{b}}$ & $0,0506 \pm 0,00^{\mathrm{a}}$ & $2,08 \pm 0,08^{\mathrm{a}}$ & $1,71 \pm 0,04^{\mathrm{a}}$ & $79,75 \pm 0,08^{\mathrm{b}}$ & $327,65 \pm 0,68^{\mathrm{a}}$ \\
\hline
\end{tabular}

PK: Pestil Kodları, TKM: Toplam Kuru Madde, TK: Toplam Karbonhidrat, E: Enerji, Analiz sonuçları "ortalama \pm standart sapma" şeklinde ifade edilmiştir. Aynı sütundaki farklı üstel ifadeye sahip ortalamalar arasında, istatistiksel açıdan anlamlı bir fark bulunmaktadır (P<0,05).

En yüksek aydınlık ve Hue* değerleri D50'ye ait iken $a^{*}, b^{*}$ ve kroma* değerleri en yüksek olan örneğin D25 olduğu tespit edilmiştir $(\mathrm{P}<0,05) . \mathrm{a}^{*}, \mathrm{~b}^{*}$, kroma* $^{*}$ değerlerinin, dut pestilinde keçiboynuzu unu ikame oranının artışına paralel bir biçimde azaldığı, toplam renk değişiminin ise arttığı gözlemlenmektedir $(\mathrm{P}<0,05)$. Bunlarla birlikte kırmızılığın azaldığı, sarılığın zamanla kaybolarak maviliğin arttığı, Hue* değerinin artışıly birlikte azalan kırmızılık ve artan maviliğin içinde koyu rengin arttığı, azalan kroma* değeri ile ise rengin parlaklığını kaybedip soluklaştığı söylenebilmektedir. Diğer bir deyişle daha soluk ve koyu kahverengimsi renkte ürünler elde edilmiştir. Literatürdeki çalışmalara bakıldığında (Yıldız, 2013; Şengül et al., 2010) benzer sonuçlara rastlanmıştır ancak $b^{*}$ değerinde farklılıklar gözlemlenmiştir. $\mathrm{Bu}$ durumun, pestil üretiminde kullanılan dut meyvesinin çeşidinin farklılığından kaynaklanabileceği düşünülmektedir.

Keçiboynuzu unu ikamesiyle üretilen dut pestillerinin duyusal özellikleri Çizelge 6'da verilmiştir. Renk bakımından DK ve D25 ile D50 ve D75 örnekleri arasında, görünüş bakımından DK ve D25 örnekleri arasında ve tat-koku bakımından ise D25 ve D 50 örnekleri arasında istatistiksel bir farklılığın olmadığı, bunun yanında keçiboynuzu ikamesinin pestillerin renk, görünüş ve tat-koku özelliklerine önemli ölçüde etki ettiği panelistler tarafından belirtilmiştir $(\mathrm{P}<0,05)$. Değişik oranlarda keçiboynuzu unu ikame edilen dut pestillerinde DK'den D75'e doğru duyusal açıdan tüm özelliklerde genel olarak bir düşüş görülmüştür $(\mathrm{P}<0,05)$. Bunun sebebi pestile kıvam özelliklerini veren nişastanın formülasyondan giderek yükselen oranlarda eksilmesinin ürünün duyusal özelliklerinde değişikliğe sebep olmasıdır. $\mathrm{Bu}$ da renk, görünüş ve tat-koku özellikleri açısından ürünler arasında farklılıklar oluşmasına yol açmıştır. Sonuçlar genel olarak değerlendirildiğinde D25'in renk ve görünüş açısından en çok beğenilen dut pestillerinden biri olduğu, tat-koku açısından ise ikinci sırada yer aldığı söylenilebilir. DK ve D25 örneklerinin duyusal açıdan panelistler tarafından daha çok tercih edildiği ortaya çıkmışırı. Keçiboynuzu unu ikamesinin oranı arttıkça panelistler tarafindan ürünün beğenisinin azaldığ dikkatleri çekmektedir.

\section{Keçiboynuzu İkameli Hurma Pestillerinin Bazı} Fiziksel, Kimyasal ve Duyusal Özellikleri

Keçiboynuzu unu ilavesi ile üretilen hurma pestillerinin bazı kimyasal özellikleri Çizelge 7'de görülmektedir. Buna göre hurma pestillerinin nem miktarları \%15,48-\%17,60, yă içerikleri \%0,04-\%0,05, protein miktarlar1 \%1,83-\%2,08, kül miktarları \%1,62$\% 1,77$, toplam karbonhidrat miktar1 \%78,53-\%81,05 ve enerji değerleri ise $322,65 \mathrm{kkal} / 100 \mathrm{~g}-\% 331,72 \mathrm{kkal} / 100 \mathrm{~g}$ aralığında tespit edilmiştir. Dut pestiline kiyasla hurma pestili örneklerinin nem miktarının daha yüksek olduğu gözlenmiştir. En yüksek nem ve en düşük toplam kuru madde miktarına sahip örnek $\mathrm{H} 25$ olarak bulunmuştur $(\mathrm{P}<0,05)$. Yağ içeriği en yüksek olan $\mathrm{H} 75$ iken, diğer örnekler arasında istatistiksel olarak anlamlı bir farklılık belirlenmemiştir $(\mathrm{P}>0,05)$. HK, protein içeriği en düşük örnek olmasıyla birlikte, keçiboynuzu ikamesi sonucunda 
hurma pestillerinin protein içeriğinin arttı̆̆ fakat bu artışın ikame oranından bağımsız olduğu tespit edilmiştir $(\mathrm{P}<0,05)$. Örneklerin kül miktarları arasında istatistiksel açıdan anlamlı bir farklılık görülmemiştir $(\mathrm{P}>0,05)$. Toplam karbonhidrat ve enerji miktarı en düşük olan örnek ise $\mathrm{H} 25$ olarak belirlenmiştir $(\mathrm{P}<0,05)$. Erik, üzüm, kayısı pestilleri ve hatta muz, ananas ve elma pürelerinden elde edilen karışı meyve pestili ile gerçekleştirilen çalışmalara (Ekşi ve Artık, 1984; Çağındı ve Ötleş, 2005; Blessing ve ark., 2015) ait veriler ile bu çalışmadan elde edilen sonuçlar karşılaştırıldığında, sonuçların birbirine benzer olduğu görülmektedir. Keçiboynuzu unu ilavesinin hurma pestili örneklerinin protein ve yağ oranlarında artışa sebep olduğu söylenilebilir.

Keçiboynuzu unu ikamesi ile üretilen hurma pestillerinin belirlenen diğer kimyasal özellikleri ise Çizelge 8'de verilmiştir. Çizelgeye göre hurma pestilinde gerçekleştirilen analizlere ait sonuçlar incelendiğinde örneklerin $\mathrm{pH}$ değerlerinin 5,75-6,08 arasında, sitrik asit cinsinden titrasyon asitliklerinin \%4,32-\%5,68 arasında, suda çözünen kuru madde değerlerinin (briks derecesinin) 20,64-30,50 arasında, HMF içeriklerinin 94,61 mg/kg$123,71 \mathrm{mg} / \mathrm{kg}$ arasında değiştiği tespit edilmiştir. Yapılan çalışmada keçiboynuzu ilavesinin hurma pestili örneklerinin $\mathrm{pH}$ değerlerinde anlamlı bir azalmaya yol açtığı görülmektedir $(\mathrm{P}<0,05)$. H25 örneği, briks derecesi ve sitrik asit cinsinden titrasyon asitliği en düşük olan örnek olarak belirlenmiştir $(\mathrm{P}<0,05)$. Çalışmada dut pestiline kıyasla hurma pestil örneklerinin HMF değerlerinin oldukça yüksek olduğu dikkatleri çekmektedir. En yüksek HMF değerine sahip örnek HK iken, HMF içerikleri bakımından tüm hurma pestili örnekleri arasında anlamlı bir farklılığın söz konusu olduğu tespit edilmiştir $(\mathrm{P}<0,05)$. Literatürde bulunan farklı pestil çeşitleriyle gerçekleştirilen çalışmalar incelendiğinde (Blessing ve ark., 2015; Şengül ve ark., 2010; Ekşi ve Artık 1984; Boz, 2012; Yıldız, 2013; Suna ve ark., 2013) benzer sonuçlara rastlanılmaktadır.

Çizelge 8 Keçiboynuzu unu ikamesi ile üretilen hurma pestillerinin belirlenen diğer kimyasal özellikleri Table 8 The other determined chemical properties of date pestil produced with carob flour substitute

\begin{tabular}{c|cccc}
\hline PK & $\mathrm{pH}$ & Titrasyon asitliği (sitrik asit cinsinden) & ${ }^{\circ}$ Briks & HMF $(\mathrm{mg} / \mathrm{kg})$ \\
\hline HK & $6,07 \pm 0,02^{\mathrm{a}}$ & $4,99 \pm 0,47^{\mathrm{b}}$ & $28,71 \pm 0,00^{\mathrm{b}}$ & $123,71 \pm 0,24^{\mathrm{a}}$ \\
$\mathrm{H} 25$ & $6,08 \pm 0,02^{\mathrm{a}}$ & $4,32 \pm 0,00^{\mathrm{c}}$ & $20,64 \pm 0,00^{\mathrm{d}}$ & $104,30 \pm 0,38^{\mathrm{c}}$ \\
$\mathrm{H} 50$ & $5,90 \pm 0,00^{\mathrm{b}}$ & $5,68 \pm 0,00^{\mathrm{a}}$ & $24,62 \pm 0,63^{\mathrm{c}}$ & $94,61 \pm 1,60^{\mathrm{d}}$ \\
$\mathrm{H} 75$ & $5,75 \pm 0,00^{\mathrm{c}}$ & $5,23 \pm 0,00^{\mathrm{a}, \mathrm{b}}$ & $30,50 \pm 0,00^{\mathrm{a}}$ & $112,96 \pm 0,44^{\mathrm{b}}$ \\
\hline
\end{tabular}

PK: Pestil Kodları, Analiz sonuçları "ortalama \pm standart sapma” şeklinde ifade edilmiştir. Aynı sütundaki farklı üstel ifadeye sahip ortalamalar arasında, istatistiksel açıdan anlamlı bir fark bulunmaktadır $(\mathrm{P}<0,05)$.

Çizelge 9 Keçiboynuzu unu ikamesiyle üretilen hurma pestillerinin mineral madde miktarları

Table 9 Mineral contents of date pestil produced with carob flour substitute

\begin{tabular}{l|ccccccc}
\hline \multicolumn{1}{c|}{$\mathrm{PK}$} & $\mathrm{Ca}(\mathrm{mg} / \mathrm{kg})$ & $\mathrm{Fe}(\mathrm{mg} / \mathrm{kg})$ & $\mathrm{K}(\mathrm{mg} / \mathrm{kg})$ & $\mathrm{Mg}(\mathrm{mg} / \mathrm{kg})$ & $\mathrm{Na}(\mathrm{mg} / \mathrm{kg})$ & $\mathrm{Zn}(\mathrm{mg} / \mathrm{kg})$ & $\mathrm{P}(\mathrm{mg} / \mathrm{kg})$ \\
\hline HK & $108,50 \pm 1,48^{\mathrm{c}}$ & $22,80 \pm 3,04^{\mathrm{c}}$ & $225,20 \pm 0,98^{\mathrm{a}}$ & $37,37 \pm 0,19^{\mathrm{d}}$ & $163,75 \pm 0,63^{\mathrm{a}}$ & $19,80 \pm 0,30^{\mathrm{a}}$ & $495,56 \pm 35,04^{\mathrm{a}}$ \\
$\mathrm{H} 25$ & $114,30 \pm 1,69^{\mathrm{c}}$ & $22,68 \pm 0,11^{\mathrm{c}}$ & $222,60 \pm 0,14^{\mathrm{a}}$ & $39,51 \pm 0,35^{\mathrm{b}}$ & $163,05 \pm 0,35^{\mathrm{a}}$ & $16,48 \pm 0,09^{\mathrm{b}}$ & $483,17 \pm 17,51^{\mathrm{a}}$ \\
$\mathrm{H} 50$ & $131,65 \pm 4,31^{\mathrm{b}}$ & $109,9 \pm 0,48^{\mathrm{b}}$ & $206,50 \pm 0,77^{\mathrm{b}}$ & $38,95 \pm 0,07^{\mathrm{c}}$ & $159,25 \pm 0,07^{\mathrm{b}}$ & $15,76 \pm 0,18^{\mathrm{c}}$ & $322,11 \pm 35,04^{\mathrm{b}}$ \\
$\mathrm{H} 75$ & $175,95 \pm 4,80^{\mathrm{a}}$ & $137,15 \pm 0,28^{\mathrm{a}}$ & $203,25 \pm 1,55^{\mathrm{c}}$ & $40,40 \pm 0,05^{\mathrm{a}}$ & $145,45 \pm 0,77^{\mathrm{c}}$ & $10,80 \pm 0,21^{\mathrm{d}}$ & $223,0 \pm 70,08^{\mathrm{b}}$ \\
\hline
\end{tabular}

PK: Pestil Kodları, Analiz sonuçları "ortalama \pm standart sapma” şeklinde ifade edilmiștir. Aynı sütundaki farklı üstel ifadeye sahip ortalamalar arasında, istatistiksel açıdan anlamlı bir fark bulunmaktadır $(\mathrm{P}<0,05)$.

Keçiboynuzu unu ikamesiyle üretilen hurma pestillerinin mineral madde miktarları Çizelge 9'da ifade edilmiştir. Buna göre hurma pestili örneklerinin kalsiyum miktarları mg/kg cinsinden 108,50-175,95 arasında, demir içerikleri $22,80 \mathrm{mg} / \mathrm{kg} \quad-\quad 137,15 \mathrm{mg} / \mathrm{kg}$ arasında, potasyum miktarları 203,25 $\mathrm{mg} / \mathrm{kg}-225,20 \quad \mathrm{mg} / \mathrm{kg}$ aralığında, sodyum miktarı 145,45-163,75 mg/kg aralığında magnezyum miktarı $37,370 \quad \mathrm{mg} / \mathrm{kg}-40,40$ $\mathrm{mg} / \mathrm{kg}$ iken, çinko miktarları 10,80-19,80 mg/kg aralığında ve fosfor miktarları 223,00 - 495,56 mg/kg$\mathrm{mg} / \mathrm{kg}$ aralığında tespit edilmiştir. Keçiboynuzu ilavesi ile pestillerin kalsiyum, demir ve magnezyum miktarlarında artış gözlemlenirken potasyum, çinko, fosfor ve sodyum içeriklerinde azalma söz konusudur $(\mathrm{P}<0,05)$. Literatürde yer alan erik, kayısı ve üzüm pestillerine ait çalışmalarda (Ekşi ve Artık, 1984; Çağındı ve Ötleş, 2005) belirlenen mineral madde içeriklerine kıyasla bu çalışmada analiz edilen hurma pestillerinin kalsiyum, potasyum, magnezyum ve sodyum miktarlarının daha düşük, demir, fosfor ve çinko miktarlarının ise benzer olduğu görülmektedir. Hurma pestillerinin belirlenen mineral madde içerikleri ile literatürde yer alan pestil örneklerinin mineral madde miktarları arasında gözlemlenen temel farklılık, literatürde hurma pestiline ait mineral madde verileri bulunamaması ve dolayısıyla sonuçların başka meyvelerden üretilen pestillere ait sonuçlarla kıyaslanmasından kaynaklanmaktadır. Çünkü pestil üretiminde kullanılan meyvenin mineral madde içeriği, elde edilen pestilin mineral kompozisyonunu önemli ölçüde etkilemektedir.

Çizelge 10'da keçiboynuzu ikamesi ile elde edilen hurma pestillerine ait kalınlık ve renk değerleri belirtilmiştir. Buna göre hurma pestili örneklerinin kalınlık değerlerine bakıldığında 0,91-1,2 mm arasında değiştiği görülmektedir. Hurma pestillerinin kalınlıkları arasında anlamlı bir farklılığın $(\mathrm{P}<0,05)$ bulunmasının sebebi, pestillerin geleneksel üretim yöntemi kullanılarak elde edilmesinden kaynaklı olarak herlenin kaput bezine serilmesi aşamasında kalınlığın standardize edilememesi olduğu düşünülmektedir. Hurma pestili örneklerinin renk değerlerinden, aydınlık değerini veren $L^{*}$ değeri 34,1438,95, kırmızılık-yeşillik indeksi olan a* değeri 2,3512,13, sarılık-mavilik indeksi olan $b^{*}$ değeri -1,77-5,54, renk tonunu gösteren Hue* değeri 24,26-178,56 ve 
doygunluk indeksi olan kroma* değeri 2,61-13,36 arasında değişmektedir. $a^{*}, b^{*}$ ve kroma* değerleri, keçiboynuzu unu ikame oranının artışına paralel bir biçimde azalış göstermesine rağmen, $\mathrm{H} 50$ ve $\mathrm{H} 75$ örnekleri arasında bu üç parametre bakımından anlamlı bir farklılık tespit edilememiştir $(\mathrm{P}>0,05)$. Hatta $\mathrm{b} *$ değeri bakımından $\mathrm{H} 25$ ve $\mathrm{H} 75$ örnekleri arasındaki fark da istatistiksel açıdan anlamlı bulunamamıştır $(\mathrm{P}>0,05)$. H25 örneği aydınlığı en düşük, Hue* değeri ise en yüksek olan örnek olarak dikkatleri çekmektedir $(\mathrm{P}<0,05)$. Toplam renk değişimi H50 ve H75 örneklerinde en yüksek iken, H25 örneğinde daha düşük belirlenmiştir $(\mathrm{P}<0,05)$. Renk parametreleri genel olarak değerlendirildiğinde pestile nişastaya ikame olarak keçiboynuzu unu katılmasıyla birlikte aydınlığın azaldığı, kırmızılığın azaldığı, sarılığın kaybolarak maviliğin arttığı, Hue* değerinin artışıyla birlikte azalan kırmızılık ve artan maviliğin içinde koyu rengin arttığı, azalan kroma* değeri ile ise rengin parlaklığını kaybedip soluklaştığı tespit edilmiştir. Diğer bir deyişle elde edilen ürünler daha soluk ve koyu kahverengimsi bir renge sahiptir. Çakır (2009)'un çalışmasında, keçiboynuzu pestillerinin renk parametrelerine ait $\mathrm{L}^{*}$ değeri $44,30-55,80$ aralığında, a* değeri 17,80-25,40 aralığında, $b *$ değeri ise 32,00-47,40 aralığında belirlenmiştir. $\mathrm{Bu}$ çalışmadaki değerler ile literatürdeki pestillere ait renk değerleri arasındaki farklılığın, pestil üretiminde farklı meyve çeşitlerinin kullanılmasından kaynaklandığı düşünülmektedir.

Keçiboynuzu unu ikamesiyle üretilen hurma pestillerinin duyusal özellikleri Çizelge 11'de değerlendirilmiştir. Çizelgeye göre panelistler, HK ve H25 ile H50 ve H75 örnekleri arasında renk ve görünüş özellikleri bakımından, H25 ve H50 örnekleri arasında ise tat-koku özellikleri bakımından istatiksel açıdan anlamlı bir farklılığın bulunmadığını ifade etmişlerdir ( $\mathrm{P}>0,05)$. Üç özellik bakımından da en beğendikleri örnek HK iken, renk ve görünüş özellikleri bakımından H25 örneğini de en az HK örneği kadar beğendiklerini ifade etmişlerdir. Sadece H25 örneğini tat-koku özelliği bakımından HK örneğinden daha düşük değerlendirdiklerini ve 2. sıraya koyduklarını belirtmişlerdir $(\mathrm{P}<0,05)$. Değişik oranlarda keçiboynuzu unu ikame edilen hurma pestillerinde de, aynı şekilde dut pestillerinde olduğu gibi, keçiboynuzu unu ikame oranı arttıç̧a duyusal analiz parametreleri puanlarında genel olarak bir düşüş görülmüştür. Formülasyona giren keçiboynuzu ununun miktarı arttıkça ürünün renk, görünüş ve tat-koku özelliklerinde değişiklikler gözlenmektedir. Dut pestilinde elde edilen duyusal analiz sonuçlarıyla benzer şekilde, keçiboynuzu ikameli hurma pestili örnekleri arasından $\mathrm{H} 25$ 'in renk, görünüş ve tat-koku özellikleri açısında en çok beğenilen pestil olduğu söylenebilir $(\mathrm{P}<0,05)$.

Çizelge 10. Keçiboynuzu unu ikamesiyle üretilen hurma pestili örneklerinin renk ve kalınlık değerleri Table 10 Colour and thickness values of date pestil produced with carob flour substitute

\begin{tabular}{l|ccccccc}
\hline PK & $\begin{array}{c}\text { Kalınlık } \\
(\mathrm{mm})\end{array}$ & L $^{*}$ & $\mathrm{a}^{*}$ & $\mathrm{~b}^{*}$ & Kroma $^{*}$ & Hue $^{*}$ & $\begin{array}{c}\text { Toplam renk } \\
\text { değişimi }\end{array}$ \\
\hline HK & $0,91 \pm 0,14^{\mathrm{b}}$ & $38,95 \pm 0,87^{\mathrm{a}}$ & $12,13 \pm 0,80^{\mathrm{a}}$ & $5,54 \pm 1,40^{\mathrm{a}}$ & $13,36 \pm 1,28^{\mathrm{a}}$ & $24,26 \pm 4,18^{\mathrm{d}}$ & - \\
H25 & $0,97 \pm 0,24^{\mathrm{a}, \mathrm{b}}$ & $34,14 \pm 0,97^{\mathrm{c}}$ & $7,64 \pm 0,33^{\mathrm{b}}$ & $-0,18 \pm 0,22^{\mathrm{b}}$ & $7,65 \pm 0,33^{\mathrm{b}}$ & $178,56 \pm 1,77^{\mathrm{a}}$ & $11,02 \pm 0,58^{\mathrm{b}}$ \\
H50 & $1,16 \pm 0,32^{\mathrm{a}, \mathrm{b}}$ & $36,61 \pm 0,42^{\mathrm{b}}$ & $2,35 \pm 0,31^{\mathrm{c}}$ & $-1,77 \pm 0,08^{\mathrm{c}}$ & $2,95 \pm 0,25^{\mathrm{c}}$ & $142,81 \pm 4,12^{\mathrm{c}}$ & $14,37 \pm 0,22^{\mathrm{a}}$ \\
H75 & $1,2 \pm 0,32^{\mathrm{a}}$ & $37,95 \pm 0,92^{\mathrm{a}}$ & $2,49 \pm 0,36^{\mathrm{c}}$ & $-0,77 \pm 0,11^{\mathrm{b}, \mathrm{c}}$ & $2,61 \pm 0,31^{\mathrm{c}}$ & $162,22 \pm 4,88^{\mathrm{b}}$ & $13,39 \pm 0,38^{\mathrm{a}}$ \\
\hline
\end{tabular}

PK: Pestil Kodları, Analiz sonuçları "ortalama \pm standart sapma” şeklinde ifade edilmiştir. Aynı sütundaki farklı üstel ifadeye sahip ortalamalar arasında, istatistiksel açıdan anlamlı bir fark bulunmaktadır $(\mathrm{P}<0,05)$.

Çizelge 11. Keçiboynuzu unu ikamesiyle üretilen hurma pestillerinin duyusal özellikleri Table 11 Sensory properties of date pestil produced with carob flour substitute

\begin{tabular}{l|ccc}
\hline PK & Renk & Görünüş & Tat-Koku \\
\hline HK & $3,6 \pm 0,52^{\mathrm{a}}$ & $3,2 \pm 0,42^{\mathrm{a}}$ & $3,7 \pm 0,48^{\mathrm{a}}$ \\
H25 & $3,9 \pm 0,32^{\mathrm{a}}$ & $3,4 \pm 0,52^{\mathrm{a}}$ & $3,1 \pm 0,57^{\mathrm{b}}$ \\
H50 & $2,5 \pm 0,53^{\mathrm{b}}$ & $2,4 \pm 0,84^{\mathrm{b}}$ & $3,0 \pm 0,47^{\mathrm{b}}$ \\
H75 & $2,8 \pm 0,63^{\mathrm{b}}$ & $1,9 \pm 0,56^{\mathrm{b}}$ & $1,9 \pm 0,32^{\mathrm{c}}$ \\
\hline
\end{tabular}

PK: Pestil Kodları, Analiz sonuçları "ortalama \pm standart sapma" şeklinde ifade edilmiştir. Aynı sütundaki farklı üstel ifadeye sahip ortalamalar arasında, istatistiksel açıdan anlamlı bir fark bulunmaktadır $(\mathrm{P}<0,05)$.

\section{Sonuç}

Çalışmada üretilen pestillere ait analiz sonuçlarına göre dut ve hurma pestili örneklerine keçiboynuzu unu ikamesi sonucunda genel olarak pestillerin yă̆ ve protein içeriğinde bir artış meydana gelmişken, kül miktarlarında ve enerji değerlerinde (H25 hariç) anlamlı bir değişiklik meydana gelmemiştir. Kalsiyum, demir ve magnezyum gibi önemli mineral maddelerin tamamını en yüksek miktarlarda yapısında bulunduran örneklerin D75 ve H75 kodlu pestiller olduğu tespit edilmiştir. Duyusal analiz sonuçları ise tüketiciler tarafından DK ve D25 ile HK ve H25 kodlu pestil örneklerinin daha çok tercih edilebileceğini ortaya koymuştur.
Sonuç olarak keçiboynuzu unu ikamesi ile dut ve hurma pestillerinin enerji değerlerinde önemli bir değişiklik meydana gelmeksizin ürünlerin protein, yağ ve bazı mineral madde içeriklerinde artış sağlanmıştır. Keçiboynuzu ikameli pestiller duyusal açıdan tüketiciler tarafından da beğenilmiştir. Keçiboynuzu unu ikamesi sonucunda protein içeriği düşük olan pestil, özellikle proteince ve mineral maddelerce daha zengin bir gida formuna dönüştürmüştür. $\mathrm{Bu}$ durum, ara öğünlerde tüketilebilecek daha sağlıklı bir atıştırmalığın eldesine imkan sağlamıştır. $\mathrm{Bu}$ çalışmada elde edilen veriler 1şığında, keçiboynuzu unu ikamesi ile fonksiyonelliği artırılan dut ve hurma pestillerinin tüketimi 
yaygınlaştırılabilecek, endüstriyel üretime proses parametreleri açısından destek olunabilecek, literatürdeki bu konuyla ilgili eksiklik giderilebilecek ve bu çalışmadan elde edilen veriler daha sonraki araştırmalara rehberlik edilebilecektir.

\section{Kaynaklar}

AOAC. 1990. Official Methods of Analysis. Association of Official Analytical Chemists. 15th Ed. Arlington. VA.

AOAC. 1995. Total sugar analysis, Official Methods of Analysis of the Association of Official Analytical Chemists. $16^{\text {th }}$ Ed. vol.II. Chapter 44. Washington DC. USA. 8-9.

Blessing I, Ekwunife OA. 2015. Production and evaluation of the physico-chemical and sensory qualities of mixed fruit leather and cakes produced from apple (Musa Pumila), banana (Musa Sapientum), pineapple (Ananas Comosus). Department of Food Science and Technology, Michael Okpara University of Agriculture, Nigerian Food Journal Volume 33:22-28.

Boz H. 2012. Dut pestilinin kimyasal, dokusal ve duyusal özelliklerine buğday unu, sakkaroz şurubu, glikoz şurubu ve pişirme süresinin etkileri. Atatürk Üniversitesi Fen Bilimleri Enstitüsü Gıda Mühendisliği Ana Bilim Dalı Doktora Tezi. Erzurum.

Çakır Ş. 2009. Keçiboynuzundan pestil üretimi ve kalitesinin belirlenmesi. İnönü Üniversitesi. Fen Bilimleri Enstitüsü. Yüksek Lisans Tezi. Malatya. 3-44.

Demirtaş Ö. 2007. Keçiboynuzu (Ceratonia siliqua) çekirdeklerinden gam üretim yollarının araştırılması. Çukurova Üniversitesi Fen Bilimleri Enstitüsü Gida Mühendisliği Ana Bilim Dalı. Yüksek Lisans Tezi.

Ekşi A, Artık N. 1984. Pestil işleme tekniği ve kimyasal bileşimi. Gıda (3): 264- 266.

IUPAC. 1979. International Union of Pure and Applied Chemistry. Standart Methods for the Analysis of Oils, Fats and Derivatives. 6th edition. Oxford: Pergamon Press.

Karkacıer M, Artık N. 1995. Keçiboynuzunun (Ceratonia siliqua L.) fiziksel özellikleri, kimyasal bileşimi ve ekstraksiyon koşulları. Gıda Tekonolojisi Derneği. 3: 131-136.

Kirk and Othmer, 1967. Industrial Gums, Encyclopedia of Chemical Technology, Vol.1, 741-752.

Kivcak B, Mert T, Ztrk HT. 2002. Antimicrobial and cytotoxic activities of ceratonia siliqua L extracts, Turk Biol. 26:197-200.

Mahmutoğlu T, Emir F, Sayg1 YB. 1996. Sun/solar drying of differently treated grapes and storage stability of dried grapes. Journal of Food Engineering. 29: 289-300.

Maskan A, Kaya S, Maskan M. 2002. Hot air and sun drying of grape leather (pestil). Journal of Food Engineering. Volume 54:81-88.

Moyls AL. 1981. Drying of apple puree. Journal of Food Science. 46: 939-942.

Ötleş S, Çağındı Ö. 2005. Comparison of some properties on the different types of pestil: a traditional product in Turkey. International Journal of Food Science and Technology. 40: 897-901.
Rada-Mendoza M, Olano A, Villamiel M. 2002. Determination of hydroxymethylfurfural in commercial jams and in fruitbased infant foods. Food Chemistry. 79:513-516.

Rtibi K, Jabri MA, Selmi S, Sebai H, Amri M, El-Benna J, Marzouki L. 2016a. Ceratonia siliqua leaves exert a strong ROS-scavenging effect in human neutrophils, inhibit myeloperoxydase in vitro and protect against intestinal fluid and electrolytes secretion in rats, RSC Adv. 6:65483- 65493.

Rtibi K, Jabri MA, Selmi S, Sebai H, Marie M, Amri L, Marzouki, J. 2016b. El Preventive effect of carob (Ceratonia siliqua L) in dextran sulfate sodium-induced ulcerative colitis in rat, RSC Adv. 6:19992-20000.

Rtibi K, Jabri MA, Selmi S, Souli A, Sebai H, El-Benna J, Amri M, Marzouki L. 2015a. Carob pods (Ceratonia siliqua L.) inhibit human neutrophils myeloperoxidase and in vitro Ros-scavenging activity. RSC Adv. 5: 84207-84215.

Rtibi K, Jabri MA, Selmi S, Souli A, Sebai H, El-Benna J, Amri M. 2015b. Gastroprotective effect of carob (Ceratonia siliqua L) against ethanol induced oxidative stress in rat, BMC complement. Altern. Med. 15: 292.

Rtibi K, Selmi S, Grami D, Amri M, Eto B, El-Benna J, Sebai H, Marzouki L. 2017. Chemical constituents and pharmacological actions of carob pods and leaves (Ceratonia siliqua L) on the gastrointestinal tract: A review. Biomedicine and Pharmacotheraphy 93: 522-528.

Rtibi K, Selmi S, Jabri MA, Mamadou G, Limas- Nzouzi N, Sebai H, El Benna J, Marzouki L, Eto B, Amri M. 2016 (c). Effects of aqueous extracts from Ceratonia siliqua L pods on small intestinal motility in rats and jejunal permeability in mice. RSC Adv. 6:44345-44353.

Sharma P, Ramchiary M, Samyor D, Das AB. 2016. Study on the phytochemical properties of pineapple fruit leather processed by extrusion cooking LWT. Food Science and Technology. 72:534-543.

Suna S, Tamer C, İncedayı B, Sinir G, Çopur Ö. 2014. Impact of drying methods on physicochemical and sensory properties of apricot pestil. Indian Journal of Traditional Knowledge. Vol. 13 (1):47-55.

Şengül M, Yıldız H, Güngör N, Okçu Z. 2010. Total phenolic content, antioxidant activity, some physical and chemical properties of pestil. Department of Food Engineering. Faculty of Agriculture. Erzurum. Asian Journal of Chemistry Vol. 22. No. 1: 448-454.

Tunalığlu R, Özkaya MT. 2003. Keçiboynuzu, Tarımsal Ekonomi Araştırma Enstitüsü, Bakış Dergisi: 3.

Türk Standartları Enstitüsü. 1998. Determination of dry matter by drying under low pressure and water content by azeotropic distillation. Fruit and Vegetable Products. TS 1129 ISO 1026. Ankara. Turkish Standart Institue.

Türk Standartları Enstitüsü. 2000. Türk Standardı. ICS 67.080.10.

Y1ld1z O. 2013. Physicochemical and sensory properties of mulberry products: Gümüşhane pestil and köme. Turkish Journal of Agriculture and Forestry. 766-769.

Yurdagel Ü, Teke İ. 1985. Keçiboynuzu meyvesinin kavrulması ile oluşan renk değişimlerinin araştırılması, Gıda Teknolojileri Derneği. 1: 39-42. 